\title{
Edukasi Pencegahan dan Pengendalian Bahaya COVID-19 Bersama SD Maarif Ketegan
}

\author{
Wuri Kristianto ${ }^{1}$, Achmad Almubaroq ${ }^{2}$, Wilujeng Rindhyani Rahayu ${ }^{3}, Z_{\text {Zuhruf Ramadhani }}{ }^{4}$, Anfal \\ Ainul Yaqin ${ }^{5}$, Lilla Puji Lestari6 \\ 1,2,3,4,5 Program Studi Manajemen, Universitas Maarif Hasyim Latif Sidoarjo, Jalan Ngelom Megare 30 \\ Sepanjang Sidoarjo \\ ${ }^{6}$ Program Studi Teknologi Laboratorium Medik, Universitas Maarif Hasyim Latif Sidoarjo, Jalan Ngelom \\ Megare 30 Sepanjang Sidoarjo
}

Correspondence: Lilla Puji Lestari (1lillapuji@gmail.com)

Received: 30 Juni 2021 - Revised: 01 Agustus 2021 - Accepted: 16 Agustus 2021

\begin{abstract}
Abstrak. Coronavirus Disease 2019 (COVID-19) adalah penyakit jenis baru yang belum pernah diidentifikasi sebelumnya pada manusia. Virus penyebab COVID-19 ini dinamakan Sars-CoV-2 Virus corona adalah zoonosis (ditularkan antara hewan dan manusia). Berdasarkan bukti ilmiah, COVID-19 dapat menular dari manusia ke manusia melalui kontak erat dan droplet, tidak melalui udara. Orang yang paling berisiko tertular penyakit ini adalah orang yang kontak erat dengan pasien COVID-19 termasuk yang merawat pasien COVID-19. Dari hal tersebut kita bisa mengetahui bahwa masih banyak masyarakat yang masih menyepelakan atau bahkan tidak mematuhi peraturan protocol pencegahan dan pengendalaian infeksi COVID-19. Oleh karena dalam kegiatan KKNT -KK Universistas Maarif Hasyim Latif Sidoarjo kami Melakukaan Edukasi terhadap siswa-siswi sekolah dasar ma'arif Ketegan Taman Sidoarjo tentang pencegahan dan pengendalian infeksi COVID-19 Kegiatan ini Dilakukan menggunakan media aplikasi zoom.Di akhir kegiatan, Pemateri melakukan evaluasi dengan cara memberikan kuisioner pada siswa-siswi tentang pencegahan dan pengendalian infeksi COVID-19 berfokus pada langkah-langkah mencuci tangan dengan baik dan benar dan etika batuk dan bersin. Edukasi pencegahan dan pengendalian infeksi COVID-19 kepada siswa-siswi sekolah dasar ma'arif Ketegan Taman Sidoarjo oleh Kelompok Fatmawati KKNT-KK Universitas Ma'arif Hasyim Latif Sidoarjo tahun 2020 dapat diselengarakan dengan lancar.
\end{abstract}

Kata kunci: COVID-19, edukasi, pencegahan dan pengendalian

Citation Format: Kristianto, W., Almubaroq, A., Rahayu, W.R., Ramadhani, Z., Yaqin, A.A. \& Lestari, L.P. (2021). Edukasi Pencegahan dan Pengendalian Bahaya COVID-19 Bersama SD Maarif Ketegan. Prosiding Seminar Nasional Abdimas Ma Chung (SENAM), 249-256. 


\section{PENDAHULUAN}

Coronavirus adalah keluarga besar virus yang menyebabkan penyakit mulai dari gejala ringan sampai berat. Ada setidaknya dua jenis coronavirus yang diketahui menyebabkan penyakit yang dapat menimbulkan gejala berat seperti Middle East Respiratory Syndrome (MERS) dan Severe Acute Respiratory Syndrome (SARS). Coronavirus Disease 2019 (COVID-19) adalah penyakit jenis baru yang belum pernah diidentifikasi sebelumnya pada manusia. Virus penyebab COVID-19 ini dinamakan SarsCoV-2. Virus corona adalah zoonosis (ditularkan antara hewan dan manusia). Penelitian menyebutkan bahwa SARS ditransmisikan dari kucing luwak (civet cats) ke manusia dan MERS dari unta ke manusia. Adapun, hewan yang menjadi sumber penularan COVID-19 ini adalah kelalawar. anda dan gejala umum infeksi COVID-19 antara lain gejala gangguan pernapasan akut seperti demam, batuk dan sesak napas. Masa inkubasi rata-rata 5-6 hari dengan masa inkubasi terpanjang 14 hari.(Kemenkes, 2020a)

Berdasarkan bukti ilmiah, COVID-19 dapat menular dari manusia ke manusia melalui kontak erat dan droplet, tidak melalui udara. Orang yang paling berisiko tertular penyakit ini adalah orang yang kontak erat dengan pasien COVID-19 termasuk yang merawat pasien COVID-19. Rekomendasi standar untuk mencegah penyebaran infeksi adalah melalui cuci tangan secara teratur, menerapkan etika batuk dan bersin, menghindari kontak secara langsung dengan ternak dan hewan liar serta menghindari kontak dekat dengan siapa pun yang menunjukkan gejala penyakit pernapasan seperti batuk dan bersin. Selain itu, menerapkan Pencegahan dan Pengendalian Infeksi (PPI) saat berada di fasilitas kesehatan terutama unit gawat darurat.(Kemenkes, 2020a)

Kasus COVID-19 di Indonesia saat ini masih cukup besar data akhir bulan November 2020 menunjukan bahwa kasus positif COVID-19 534.266 kasus Pasien sembuh 445.793 orang. Pasien meninggal 16.815 orang.(Kemenkes, 2020b) Dari hal tersebut kita bias mengetahui bahwa masih banyak masyarakat yang masih menyepelakan atau bahkan tidak mematuhi peraturan protocol pencegahan dan pengendalaian infeksi COVID-19. Oleh karena dalam kegiatan KKNT -KK Universistas Maarif Hasyim Latif Sidoarjo kami Melakukaan Edukasi terhadap siswa-siswi sekolah dasar ma'arif Ketegan Taman Sidoarjo tentang pencegahan dan pengendalian infeksi COVID-19.

Berdasarkan bukti yang tersedia, COVID-19 ditularkan melalui kontak dekat dan droplet, bukan melalui transmisi udara. Orang-orang yang paling berisiko terinfeksi adalah 
mereka yang berhubungan dekat dengan pasien COVID-19 atau yang merawat pasien COVID-19. Tindakan pencegahan dan mitigasi merupakan kunci penerapan di pelayanan kesehatan dan masyarakat. Langkah-langkah pencegahan yang paling efektif di masyarakat meliputi: melakukan kebersihan tangan menggunakan hand sanitizer jika tangan tidak terlihat kotor atau cuci tangan dengan sabun jika tangan terlihat kotor, menghindari menyentuh mata, hidung dan mulut, terapkan etika batuk atau bersin dengan menutup hidung dan mulut dengan lengan atas bagian dalam atau tisu, lalu buanglah tisu ke tempat sampah, pakailah masker medis jika memiliki gejala pernapasan dan melakukan kebersihan tangan setelah membuang masker, menjaga jarak (minimal 1 meter) dari orang yang mengalami gejala gangguan pernapasan.(Yurianto, 2020).

\section{METODE PELAKSANAAN}

Kegiatan ini Dilakukan menggunakan media aplikasi zoom, sebelum kegiatan dilakukan Kelompok Fatmawati KKNT-KK Universitas Maarif Hasyim latif Sidoarjo Melakukan persipan diantaranya membuat link meeting aplikasi zoom, menyiapkan materi edukasi pencegahan dan penanggulangan COVID-19, slide presentasi, dan menyiapkan reward untuk siswa-siswi yang aktif dalam kegiatan. Metode pelaksanaan kegiatan meliputi ceramah, Tanya jawab dan evaluasi.

Kegiatan dilakukan pada hari minggu 06 Desember 2020 bertempat di gedung B Universitas Maarif Hasyim latif Sidoarjo untuk Kelompok Fatmawati KKNT-KK sedangkan siswa-siswi sekolah dasar ma'arif Ketegan Taman Sidoarjo bertempat dirumah masing masing. Kami memberian link zoom pada siswa siswa untuk masuk kemudian memberikan meteri tentang pencegahan dan penangulangan COVID-19, setelah pemberian materi kami memberikan kesempatan pada siswa-siswi untuk bertanya apabia ada hal yang masih belum dimengerti. Kemudian pada hari Senin 07 November 2020 kami memberikan reward kepada siswa-siswi yang aktif dalam kegiatan.

\section{HASIL DAN PEMBAHASAN}

Kegiatan dimulai dengan ketua kelompok KKNT-KK UMAHA 2020 Fatmawati mengirim link zoom kepada siswa-siswi sekolah dasar ma'arif Ketegan Taman Sidoarjo. Kegiatan ini bertujuan untuk meningkatkan pengetahuan siswa-siswi sekolah dasar ma'arif Ketegan Taman Sidoarjo terhadap bahaya dari COVID-19, pencegahan dan pengendalian 
infeksi COVID-19. Sebelum kegiatan adapun pembuatan link zoom dan materi power point (Gambar 1).

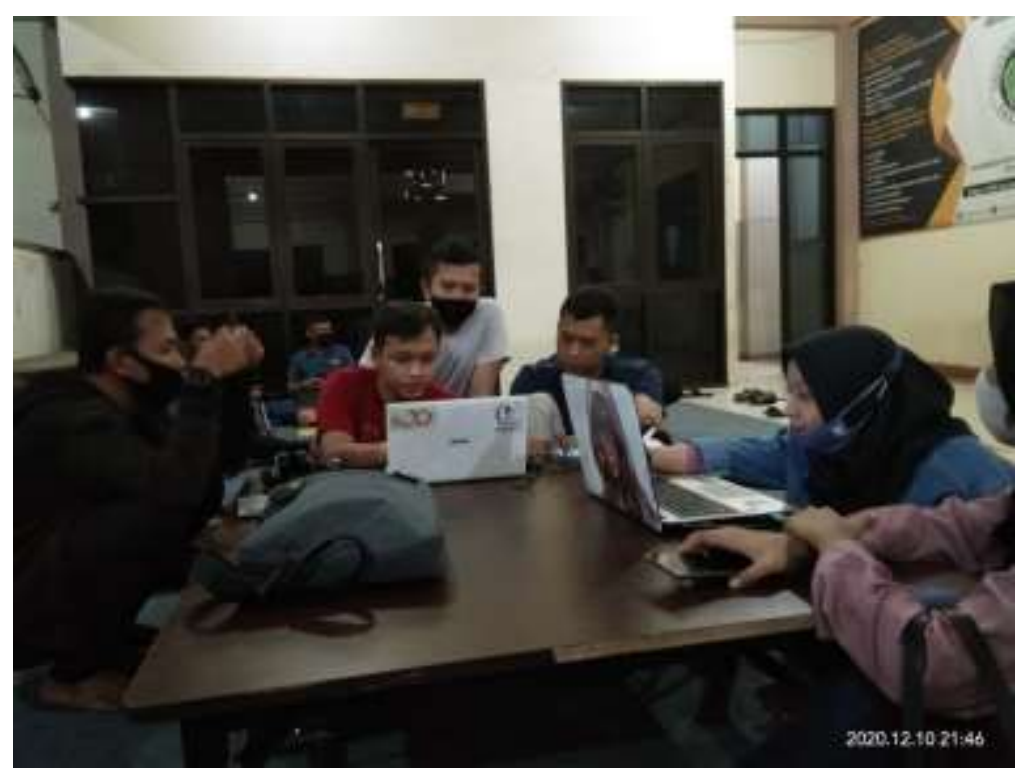

Gambar 1. Proses Pembuatan link meeting zoom dan materi pencegahan dan pengendalian infeksi COVID-19 slide presentasi.

Siswa-siswi memasuki zoom meeting, kegiatan dilanjutkan dengan pemberian materi pencegahan dan pengendalian infeksi COVID-19 menggunakan power point (Gambar 2). Materi disampaikan menggunakan bahasa-bahasa yang mudah difahami dan dengan komunikasi yang sesuai untuk siswa-siswi sekolah dasar supaya siswa-siswi dapat memahami materi dengan baik.

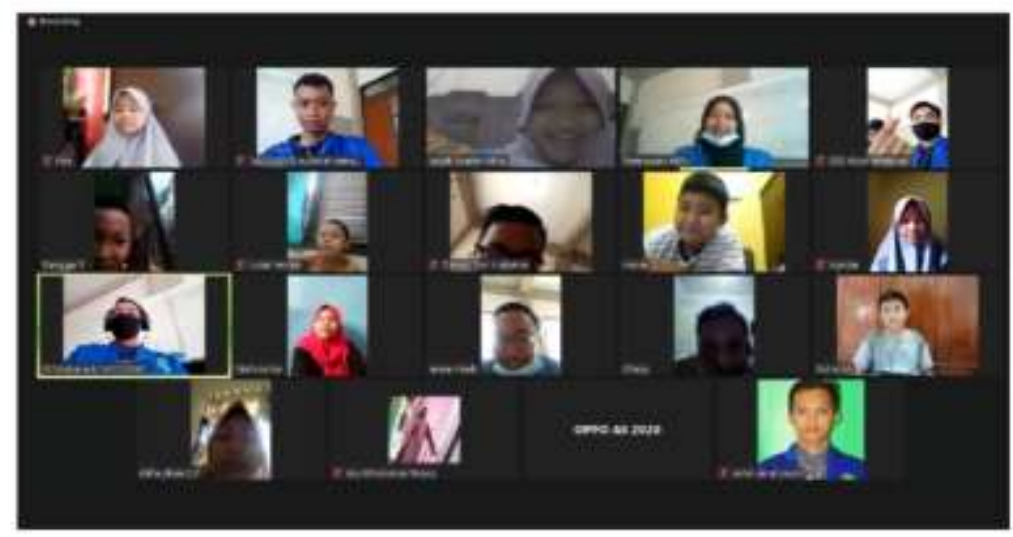




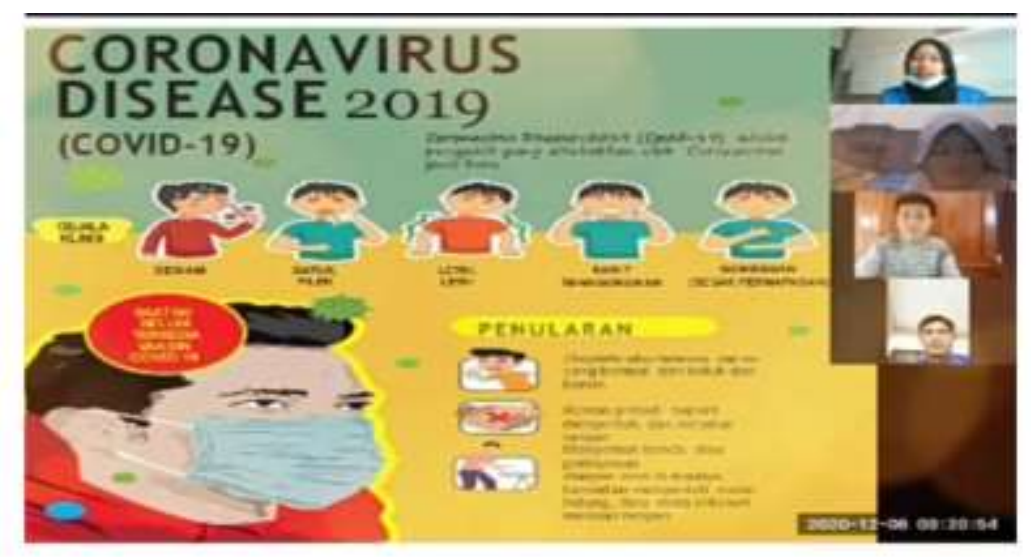

Gambar 2. Pemberian materi pencegahan dan penangulangan infeksi COVID-19

Setelah pemberian materi, siswa-siswi diberikan kesempatan untuk bertanya. Hal ini bertujuan apabila dalam pemberian materi pencegahan dan pengendalian infeksi COVID19 terdapat hal yang kurang atau tidak difahami. Siswa-siswi mengajukan beberapa pertanyaan kemudian pemateri menjawab (Gambar 3).

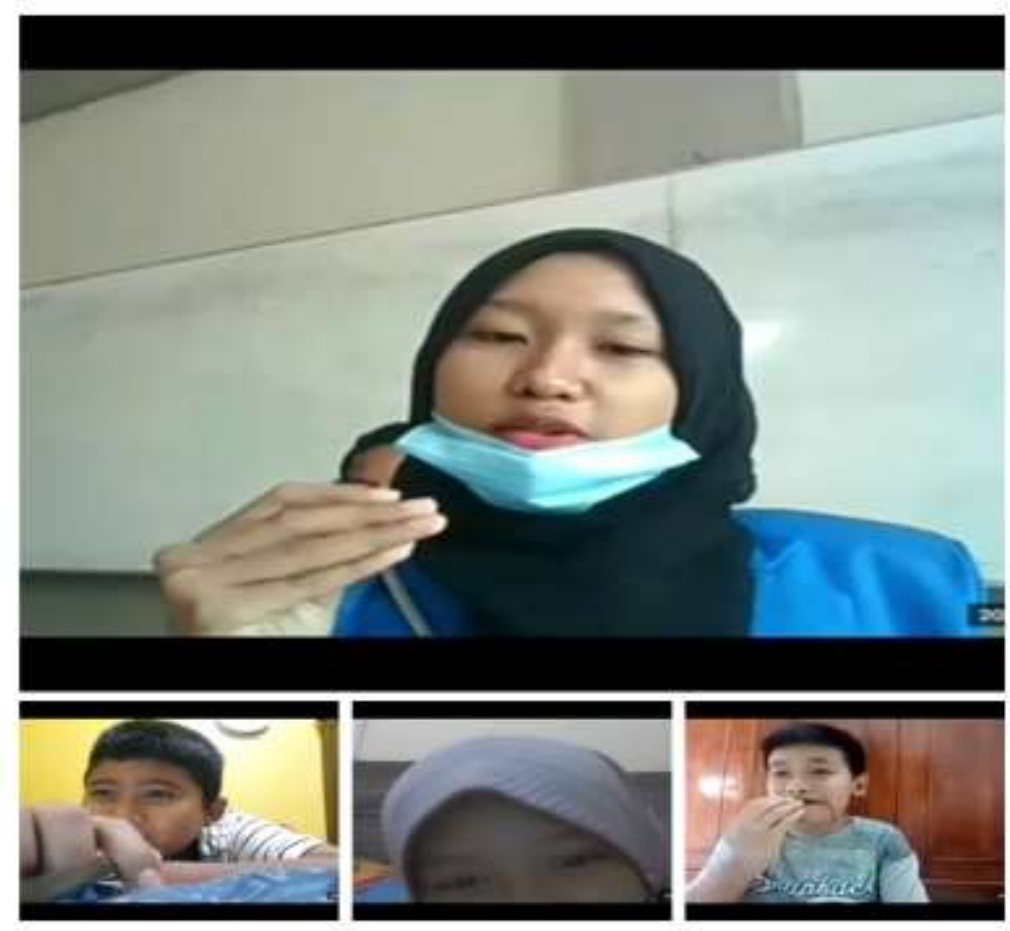

Gambar 3. Tanya jawab tentang pencegahan dan pengendalian COVID-19

Di akhir kegiatan, pemateri melakukan evaluasi dengan cara memberikan kuisioner pada siswa-siswi tentang pencegahan dan pengendalian infeksi COVID-19 berfokus pada langkah-langkah mencuci tangan dengan baik dan benar dan etika batuk dan bersin. Dari 
hasil evaluasi siswa-siswi pemahaman tentang pencegahan dan pengendalian COVID-19 khususnya dalam mencuci tangan dan etika batuk dan bersin cukup baik (Gambar 4).
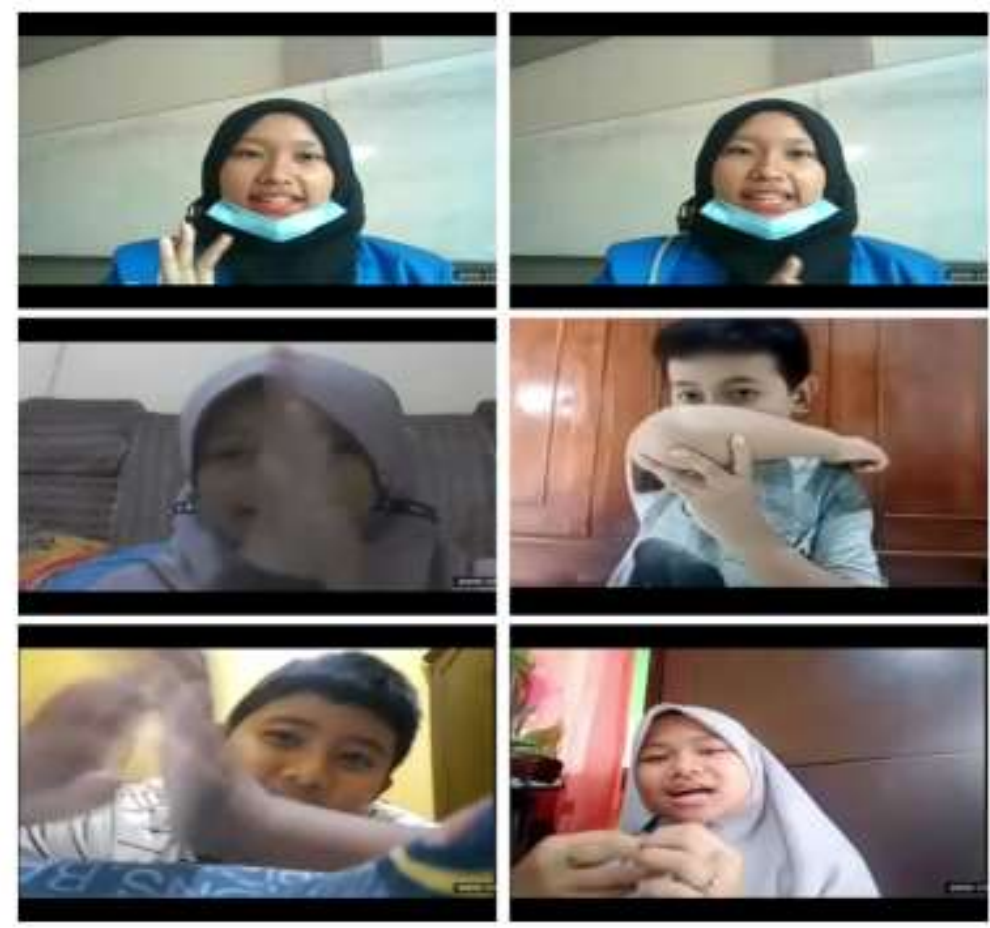

Gambar 4. Evaluasi tentang pencegahan dan pengendalian infeksi COVID-19

Dan sebagai ucapan terima kasih dari kelompok Fatmawati KKNT-KK UMAHA 2020 kepada siswa-siswi sekolah dasar ma'arif Ketegan Taman Sidoarjo karena sudah mengikuti kegiatan edukasi tentang pencegahan dan pengendalian infeksi COVID-19, kelompok memberikan reward terhadap masing-masing siswa-siswi (Gambar 5). Selanjutnya, dilakukan foto kelompok Fatmawati KKNT-KK sebagai penutup kegiatan edukasi pencegahan dan pengendalian infeksi COVID-19 terhadap siswa-siswi Sekolah Dasar Ma'arif Ketegan Taman Sidoarjo terhadap bahaya dari COVID-19 (Gambar 6). 


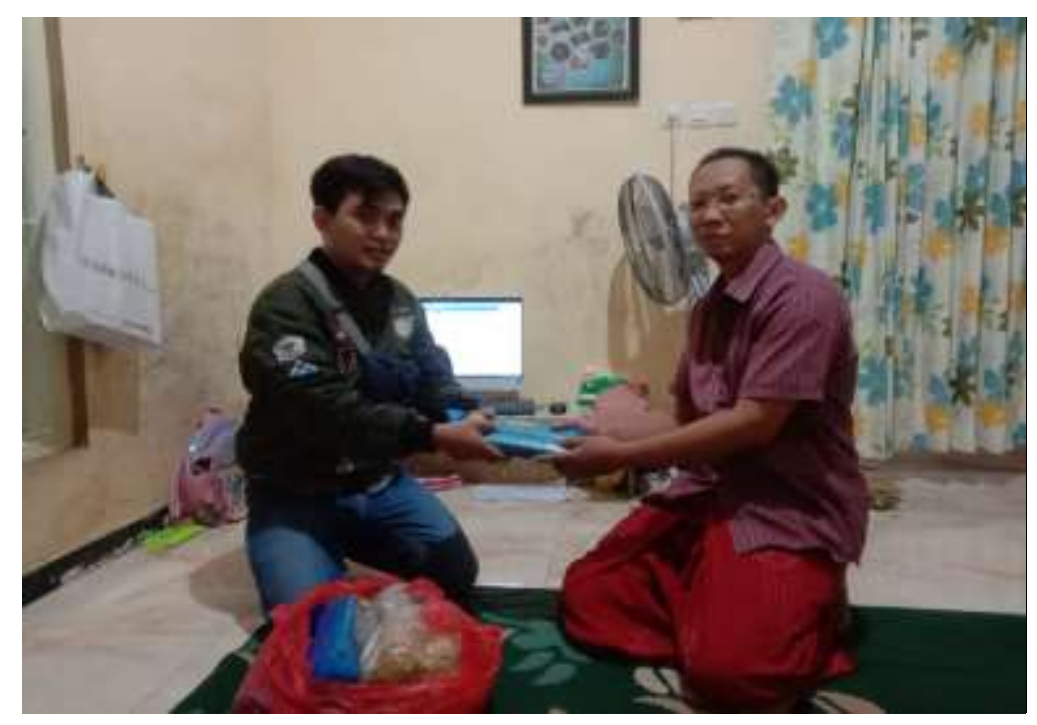

Gambar 5. Pemberian reward dari kelompok KKNT-KK Fatmawati UMAHA 2020

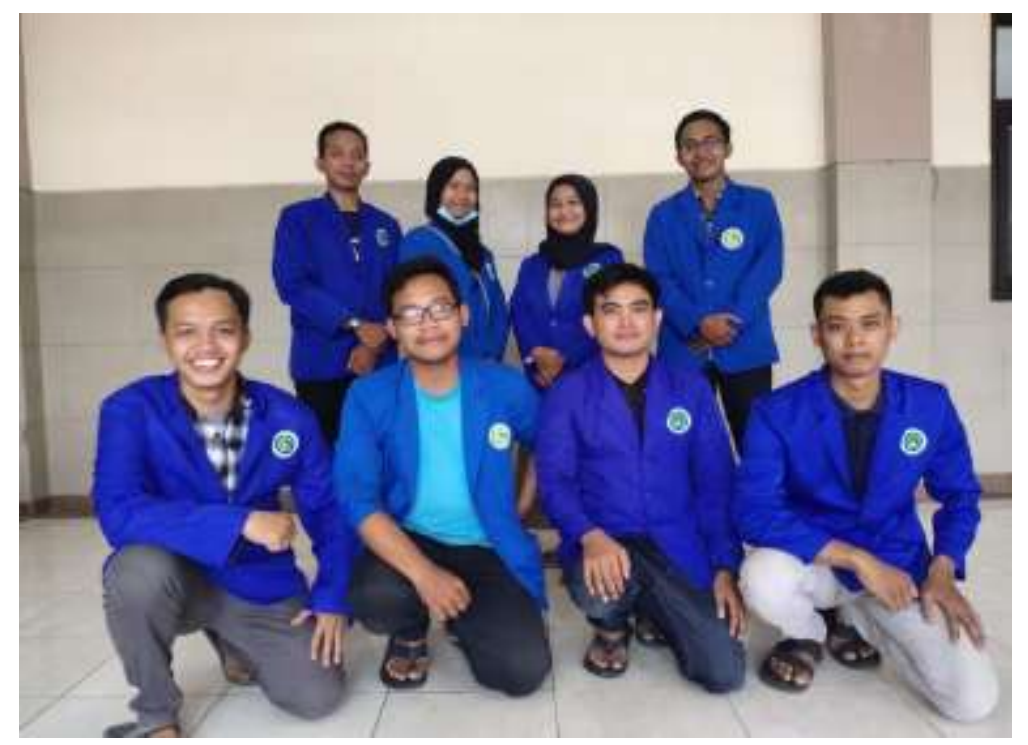

Gambar 6. Kelompok Fatmawati KKNT-KK UMJAHA 2020 melakukan foto dikahir kegiatan.

\section{KESIMPULAN}

Kegiatan edukasi pencegahan dan pengendalian infeksi COVID-19 kepada siswasiswi sekolah dasar ma'arif Ketegan Taman Sidoarjo oleh Kelompok Fatmawati KKNTKK Universitas Ma'arif Hasyim Latif Sidoarjo tahun 2020 dapat diselengarakan dengan lancar. Dari kegiatan ini dapat meningkatkan pengetahuan siswa-siswi sekolah dasar ma'arif Ketegan Taman Sidoarjo tentang pencegahan dan pengendalian infeksi COVID-19. 


\section{UCAPAN TERIMA KASIH}

Puji Syukur kami Panjatkan kehadirat Tuhan Yang Maha Esa karena atas berkat, rahmat dan karunianya sehingga kami dapat menyelesaikan artikel ini tepat pada waktunya. Kami menguapkan terima kasih kepada pihak LPM/LPPM dan Bapak Agung Supangkat, SH.,MH selaku dosen penggerak KKNT-KK UMAHA 2020 kelompok Fatmawati. Terima kasih juga kami ucapkan kepada teman-teman sekalian yang telah banyak membantu hingga artikel ini selesai dikerjakan. Kami menyadari bahwa dalam penulisan artikel ini masih jauh dari sempurna. Oleh karena itu, kami mengharapkan kritik dan saran yang bersifat membangun. Akhir kata kami ucapkan terima kasih.

\section{DAFTAR PUSTAKA}

Kemenkes. (2020a). Pedoman kesiapan menghadapi COVID-19. Pedoman Kesiapan Menghadapi COVID-19, 0-115.

Kementerian Kesehatan RI (2020b) 'Langkah-langkah Strategis Kemenkes RI Untuk dan dalam Konteks Reformasi Sistem Kesehatan di Indonesia Visi dan Misi Presiden Agenda Pembangunan : "Peningkatan SDM Berkualitas dan Berdaya Saing"

Yurianto, A. (2020). Pedoman Pencegahan dan Pengendalian Coronavirus Disease (COVID-19). Germas, 0-115.

(C) 2021 by authors. Content on this article is licensed under a Creative Commons Attribution 4.0 International license. (http://creativecommons.org/licenses/by/4.0/). 